\begin{tabular}{|l|l|l||}
\hline \multicolumn{2}{|c|}{ PublisherInfo } \\
\hline \hline PublisherName & $:$ & BioMed Central \\
\hline \hline PublisherLocation & $:$ & London \\
\hline \hline PublisherImprintName & $:$ & BioMed Central \\
\hline \hline
\end{tabular}

\title{
Modeling RNA secondary structure
}

\begin{tabular}{|l|l|l||}
\hline \multicolumn{2}{|c|}{ ArticleInfo } \\
\hline \hline ArticleID & $:$ & 3937 \\
\hline \hline ArticleDOI & $:$ & $10.1186 /$ gb-2001-2-8-reports2007 \\
\hline \hline ArticleCitationID & $:$ & reports2007 \\
\hline \hline ArticleSequenceNumber & $:$ & 28 \\
\hline \hline ArticleCategory & $:$ & Web report \\
\hline ArticleFirstPage & $:$ & 1 \\
\hline \hline ArticleLastPage & $:$ & 4 \\
\hline \hline & & RegistrationDate : 2001-7-11 \\
ArticleHistory & $:$ & Received \\
\hline \hline ArticleCopyright & $:$ & BioMed Central Ltd2001 \\
\hline \hline ArticleGrants & $:$ & \\
\hline \hline
\end{tabular}




\begin{tabular}{|l|l|l||}
\hline ArticleContext & $:$ & 130592288 \\
\hline
\end{tabular}

\section{Steven G Gray}

\section{Abstract}

The mfold server has a simple interface that allows any researcher to analyze a submitted RNA sequence for various secondary structures using up-to-date algorithms and free-energy rules.

\section{Mirror site}

mfold at the Canadian Bioinformatics Resource and MBCMR mfold server

\section{Content}

The mfold server has a simple interface that allows any researcher to analyze a submitted RNA sequence for various secondary structures using up-to-date algorithms and free-energy rules. The site also offers analysis of DNA folding. When submitting a sequence for folding analysis, the user is allowed to change many parameters, including various constraints. Batch processing is allowed, and the user is prompted to determine how they want the results to be presented. For example, you can choose the resolution of image files generated or how the folded structure is annotated after analysis. The maximum size of sequence for analysis is 3,000 bases.

\section{Navigation}

Navigation throughout the site is very simple. For each option or parameter that can be altered, the user is provided with links to explanations for each, allowing the researcher to make an informed decision about which to select. The current server runs mfold version 3.1, in which the folding temperature is fixed at $37^{\circ} \mathrm{C}$, but users have the option of running the query on a separate server running RNA mfold version 2.3, which allows the temperature to be varied.

\section{Reporter's comments}




\section{Best feature}

The mfold server's best feature is its simplicity and ease of use. All you need to do is click and paste, select your options and run. If you do not like to fold your structures online, you can download a PC version of mfold called RNAstructure, version 3.21, from the site. The latest version is in fact RNAstructure 3.6, which can be downloaded from Turner group RNA biophysical chemistry. The site is extremely useful for researchers who might worry about RNA secondary structure interfering with their experiments. I have used it extensively to check secondary structures of RNA probes for potential problems at expected annealing temperatures.

\section{Worst feature}

The limitation with the online service is the maximum number of bases allowed - 3,000. For most researchers this will be perfectly adequate. I wished to fold a larger structure (approximately 4,500 bases), however, and so found it slightly limited. One problem I encountered was that extensive repeat regions can cause the server problems.

\section{Related websites}

Further information about RNA folding can be found at Michael Zuker's laboratory. A related web report can be found at Genome Biology 1:reports208.

\section{Table of links}

mfold

mfold at the Canadian Bioinformatics Resource

MBCMR mfold server

Turner group RNA biophysical chemistry

Michael Zuker's laboratory

Genome Biology 1:reports208 


\section{References}

1. mfold.

This PDF file was created after publication. 